\title{
Timescale dependence of environmental controls on methane efflux from Poyang Hu, China
}

\author{
Lixiang Liu ${ }^{1}$, Ming $\mathrm{Xu}^{1,2}$, Renqiang $\mathrm{Li}^{1}$, and Rui Shao ${ }^{1,3}$ \\ ${ }^{1}$ Key Laboratory of Ecosystem Network Observation and Modeling, Institute of Geographic Sciences and \\ Natural Resources Research, Chinese Academy of Sciences, Beijing 100101, China \\ ${ }^{2}$ Center for Remote Sensing and Spatial Analysis, Department of Ecology, Evolution and Natural Resources, \\ Rutgers University, New Brunswick, NJ 08901, USA \\ ${ }^{3}$ University of Chinese Academy of Sciences, Beijing 100049, China \\ Correspondence to: Ming Xu (mingxu@igsnrr.ac.cn)
}

Received: 8 July 2016 - Discussion started: 23 August 2016

Revised: 13 February 2017 - Accepted: 28 February 2017 - Published: 18 April 2017

\begin{abstract}
Lakes are an important natural source of $\mathrm{CH}_{4}$ to the atmosphere. However, the multi-seasonal $\mathrm{CH}_{4}$ efflux from lakes has been rarely studied. In this study, the $\mathrm{CH}_{4}$ efflux from Poyang $\mathrm{Hu}$, the largest freshwater lake in China, was measured monthly over a 4-year period by using the floating-chamber technique. The mean annual $\mathrm{CH}_{4}$ efflux throughout the 4 years was $0.54 \mathrm{mmol} \mathrm{m}^{-2} \mathrm{day}^{-1}$, ranging from 0.47 to $0.60 \mathrm{mmol} \mathrm{m}^{-2} \mathrm{day}^{-1}$. The $\mathrm{CH}_{4}$ efflux had a high seasonal variation with an average summer (June to August) efflux of $1.34 \mathrm{mmol} \mathrm{m}^{-2} \mathrm{day}^{-1}$ and winter (December to February) efflux of merely $0.18 \mathrm{mmol} \mathrm{m}^{-2} \mathrm{day}^{-1}$. The efflux showed no apparent diel pattern, although most of the peak effluxes appeared in the late morning, from 10:00 to 12:00 CST (GMT + 8). Multivariate stepwise regression on a seasonal scale showed that environmental factors, such as sediment temperature, sediment total nitrogen content, dissolved oxygen, and total phosphorus content in the water, mainly regulated the $\mathrm{CH}_{4}$ efflux. However, the $\mathrm{CH}_{4}$ efflux only showed a strong positive linear correlation with wind speed within 1 day on a bihourly scale in the multivariate regression analyses but almost no correlation with wind speed on diurnal and seasonal scales.
\end{abstract}

\section{Introduction}

Methane $\left(\mathrm{CH}_{4}\right)$ contributes to about $20 \%$ of global warming in terms of radiative forcing, and its concentration in the atmosphere increased at a rate of 0.5 ppb year $^{-1}$ in 1999-2006; this rate rapidly increased to $6 \mathrm{ppb}$ year $^{-1}$ from 2007 to 2011 (IPCC, 2013). Although the total global lake area accounts for approximately $3.7 \%$ of the Earth's non-glaciated land area (Verpoorter et al., 2014), $\mathrm{CH}_{4}$ emissions from global lakes account for up to $14.9 \%$ of natural $\mathrm{CH}_{4}$ emissions (IPCC, 2013). However, this estimate has been associated with large uncertainties because of the high spatial and temporal variations of $\mathrm{CH}_{4}$ emissions and the insufficient multiseasonal measurements of $\mathrm{CH}_{4}$ effluxes, especially in tropical and subtropical lakes (Yang et al., 2011; Ortiz-Llorente and Alvarez-Cobelas, 2012; Bastviken et al., 2015; Li and Bush, 2015).

$\mathrm{CH}_{4}$ effluxes in lakes feature high temporal variations (Käki et al., 2001; Xing et al., 2004, 2005, 2006; Duan et al., 2005; Palma-Silva et al., 2013). For example, previous studies found that the mean $\mathrm{CH}_{4}$ effluxes over 1 day were 0.018 and $68.27 \mathrm{mmol} \mathrm{m}^{-2}$ day $^{-1}$ (Xing et al., 2004; Duan et al., 2005; Chen et al., 2007; Podgrajsek et al., 2014); even larger variations were found on a seasonal scale (Xing et al., 2005, 2006; Duan et al., 2005; Ortiz-Llorente and AlvarezCobelas, 2012; Wik et al., 2014). These large variations in $\mathrm{CH}_{4}$ effluxes highlight the importance of frequent and multiseasonal measurements (Bastviken et al., 2008, 2015; Chen et al., 2013). Unfortunately, most earlier studies on $\mathrm{CH}_{4}$ emissions were based on short-term measurements, ranging from daily to seasonal scales, and were conducted during the daytime (Xing et al., 2004, 2005; Duan et al., 2005; SchrierUijl et al., 2011; Rõõm et al., 2014). To our knowledge, multi-seasonal measurements of $\mathrm{CH}_{4}$ effluxes have only been 
conducted in high-latitude lakes (Utsumi et al., 1998a, b; Huttunen et al., 2003; Rõõm et al., 2014; Wik et al., 2014), and few studies on tropical and subtropical lakes (Xing et al., 2005, 2006; Ortiz-Llorente and Alvarez-Cobelas, 2012), especially large ones, had measurement durations longer than 1 year.

The magnitude of $\mathrm{CH}_{4}$ emission mainly depends on the dynamic balance between the microbial processes of $\mathrm{CH}_{4}$ production, oxidation, physical transportation from the anaerobic zone to the atmosphere in lakes, and regulation by multiple, interconnected physical, chemical, and biological variables (Sun et al., 2012; Liu et al., 2013; Serrano-Silva et al., 2014; Rasilo et al., 2015). $\mathrm{CH}_{4}$ production and oxidation are microbial processes regulated by organic carbon loading, dissolved organic matter, lake nutrient status, and $\mathrm{N}$ availability (Bridgham et al., 2013; Liu et al., 2013; Hershey et al., 2014; Rasilo et al., 2015); temperature (Liikanen et al., 2003; Marotta et al., 2014; Yvon-Durocher et al., 2014); lake depth and size (Juutinen et al., 2009; Rasilo et al., 2015); pH, $\mathrm{O}_{2}, \mathrm{NO}_{3}^{2-}, \mathrm{Fe}^{3+}$, and $\mathrm{SO}_{4}^{2-}$ in the sediment and water column (van Bodegom and Scholten, 2001; Schrier-Uijl et al., 2011; Bridgham et al., 2013); and populations and potential activities of methanogens and methanotrophs (Segers, 1998; van Bodegom and Scholten, 2001; Liu et al., 2015; Liu and $\mathrm{Xu}, 2016) . \mathrm{CH}_{4}$ transportation is driven by three major mechanisms, namely, molecular diffusion, bubble ebullition, and plant-mediated transportation (Bridgham et al., 2013; Chen et al., 2013; Zhu et al., 2016). These mechanisms are affected by water stratification and seasonal overturns of the water mass, which are determined by temperature (PalmaSilva et al., 2013; Rõõm et al., 2014), wind-forced mixing (Wanninkhof, 1992; Palma-Silva et al., 2013), water depth (Liu et al., 2013), boundary layer dynamics (Poindexter et al., 2016; Anthony and Macintyre, 2016), hydrostatic pressure (Chanton, 1989), and different vascular plants (Juutinen et al., 2009; Zhu et al., 2016). Most studies examined $\mathrm{CH}_{4}$ emissions and their influencing factors in small lakes because of their large contribution to the global $\mathrm{CH}_{4}$ budget (Bastviken et al., 2004; Downing, 2010; Bartosiewicz et al., 2015; Holgerson and Raymond, 2016). Although small lakes are a large source of atmospheric $\mathrm{CH}_{4}, \mathrm{CH}_{4}$ emissions from large lakes were not neglected due to their large areas (Bastviken et al., 2010; Rasilo et al., 2015; Townsend-Small et al., 2016). However, few studies reported temporal $\mathrm{CH}_{4}$ emissions and their key regulating factors on different temporal scales in large lakes. Therefore, investigating the impacts of physical and biological factors on temporal $\mathrm{CH}_{4}$ effluxes based on multi-seasonal measurements in a large lake is also important to estimate lake $\mathrm{CH}_{4}$ emissions.

Poyang $\mathrm{Hu}$, a subtropical lake, is the largest freshwater lake in China, but its multi-seasonal $\mathrm{CH}_{4}$ emissions have not been adequately measured. In our previous study, we explored the spatial variations of $\mathrm{CH}_{4}$ efflux over the lake with 44 sampling locations (Liu et al., 2013). In addition, we also found that microbial biomass and community structure in- fluenced $\mathrm{CH}_{4}$ efflux from Poyang $\mathrm{Hu}$ greatly (Liu and $\mathrm{Xu}$, 2016). In this study, we measured the $\mathrm{CH}_{4}$ efflux at three sites which we chose on the basis of our previous result over the course of 4 years in Poyang Hu to (1) examine the multiseasonal mean $\mathrm{CH}_{4}$ efflux; (2) explore the $\mathrm{CH}_{4}$ efflux dynamics, including diel and seasonal variations; and (3) quantify the relationships between the $\mathrm{CH}_{4}$ efflux and environmental factors and identify the possible factors driving $\mathrm{CH}_{4}$ effluxes on different temporal scales.

\section{Materials and methods}

\subsection{Site description}

Poyang $\mathrm{Hu}\left(28^{\circ} 22^{\prime}-29^{\circ} 45^{\prime} \mathrm{N}, 115^{\circ} 47^{\prime}-116^{\circ} 45^{\prime} \mathrm{E}\right)$ is located in southern China in Jiangxi Province, with a surface area of $3283 \mathrm{~km}^{2}$ and a total catchment area of $162000 \mathrm{~km}^{2}$, which is separated from the northern and southern parts by the Songmen Mountain. Poyang Hu receives water input from five main tributaries, namely, the Raohe, Xinjiang, Fuhe, Ganjiang, and Xiu Shui. The climate is humid subtropical with a mean annual temperature of $17.5^{\circ} \mathrm{C}$ and an annual precipitation of $1680 \mathrm{~mm}$ (Ye et al., 2011). Vegetation in the lake is composed of macrophytes, including Carex sp. (Carex cinerascens Kükenth. and Carexargyi Levl. et Vant.) and Artemisia selengensis in the hydrophyte zone and the main submerged aquatic macrophytes, including Ceratophyllum demersum, Potamogeton malaianus, Potamogeton crispus, and Hydrilla verticillata (Wang et al., 2011).

This study was conducted near the Poyang Lake Laboratory of the Wetland Ecosystem Research Station (operated by the Chinese Academy of Sciences), which is located in the northern subbasin of Poyang Hu in Xingzi County, Jiangxi Province (Fig. 1). The five tributaries flow into the lake in the southeast of Xingzi County, which then joins with the Yangtze River. The water level fluctuated dramatically from 7.78 to $18.57 \mathrm{~m}$ above sea level (Wu Song station) between the wet (April to September) and dry seasons (October to March) during the study period because of rainfall and Three Gorge management. Poyang $\mathrm{Hu}$ is not stratified (Zhu and Zhang, 1997), with mean and maximum depths of 8 and $23 \mathrm{~m}$, respectively. The mean concentrations of total nitrogen (TN), total phosphorous (TP), suspended solids (SSs), and chlorophyll $a(\mathrm{Chl} a$ ) in Poyang Hu were 3.45, 0.11, 39.98, and $9.04 \mathrm{mg} \mathrm{L}^{-1}$, respectively (Yao et al., 2015).

\section{$2.2 \mathrm{CH}_{4}$ efflux measurements}

The $\mathrm{CH}_{4}$ efflux was measured using floating chambers, including both ebullition and diffusive fluxes (Bastviken et al., 2004, 2010). The floating chamber was constructed using a PVC pipe $100 \mathrm{~cm}$ in length and $20 \mathrm{~cm}$ in diameter with Styrofoam floats attached to the sides. The floating chambers were inserted $80 \mathrm{~cm}$ into the water and $20 \mathrm{~cm}$ above the water surface to minimize the perturbation of the surface wa- 


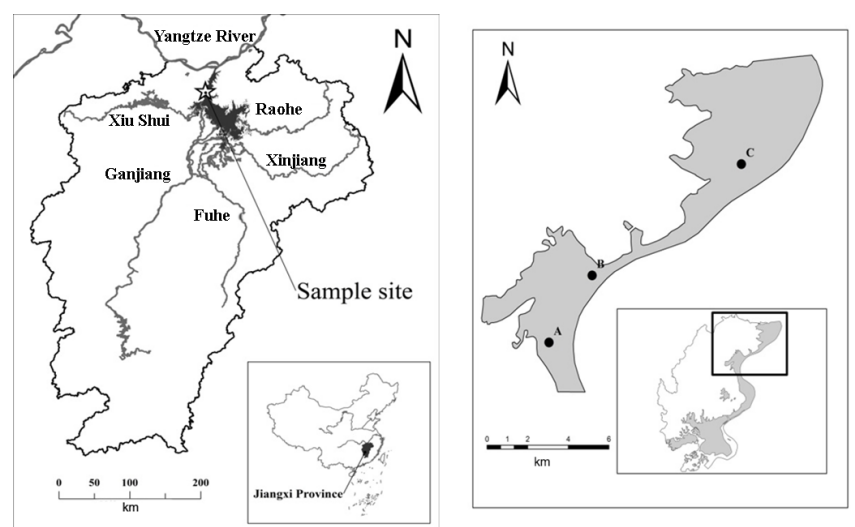

Figure 1. Location of sampling sites in Poyang $\mathrm{Hu}$.

ter flow to the pressure inside the chambers. We tested the chamber system with different insertion depths in the laboratory and field and found that the current depth of about $80 \mathrm{~cm}$ could effectively prevent the impacts of the surrounding Styrofoam floats while maintaining the chamber balance in moderate winds. A similar design of floating chambers was used in previous studies (Lorke et al., 2015; Zhao et al., 2015). Earlier studies found that floating chambers should be situated at the water surface in a flowing-water system to minimize the "drag" effect of flowing water on chamber pressure (Bastviken et al., 2010; Vachon and Prairie, 2013; McGinnis et al., 2015). However, the water in Poyang Hu did not have an apparent directional flow except for some waves during the measurement period. So the insertion depth was deeper than those of previous studies to avoid the impact of waves in Poyang $\mathrm{Hu}$ on the chamber body in the current study. A detailed description of the floating-chamber system can be found in Liu et al. (2013). So we measured the total $\mathrm{CH}_{4}$ efflux including both ebullition and diffusive effluxes and cannot differentiate between ebullitive and diffusive fluxes by means of our chamber.

We collected a gas sample (ambient concentration) immediately after the chamber was closed and three other samples at a 20 min interval for $1 \mathrm{~h}$. The gas was extracted into a $12 \mathrm{~mL}$ evacuated glass vial by a $2 \mathrm{~mL}$ syringe needle with an air pump, which enhanced the pressure in the vial to 3 bars. Subsequently, the gas samples were transported immediately to a laboratory for $\mathrm{CH}_{4}$ concentration analysis. The $\mathrm{CH}_{4}$ concentration was measured using a gas chromatograph (GC) equipped with a flame ionization detector (GC7890A, Agilent Technologies, Inc., Santa Clara, CA, USA). We used nitrogen $\left(\mathrm{N}_{2}\right)$ as the carrier gas, which ran at a flow rate of $30 \mathrm{~mL} \mathrm{~min}^{-1}$. We calibrated the gas chromatograph for every four samples with a calibration gas of $2.03 \mathrm{ppm}$ at $99.92 \%$ precision (China National Research Center for Certified Reference Materials, China). The oven and detector temperatures of the $\mathrm{GC}$ were set to 55 and $250^{\circ} \mathrm{C}$, respectively.
Calculation of the $\mathrm{CH}_{4}$ efflux was based on the $\mathrm{CH}_{4}$ concentration of the four samples using a linear regression model, which was calculated on the basis of the slope of the concentration change during the whole period when the chamber was closed. Data quality control was conducted following the method of Rasilo et al. (2015) before the regression models were fitted. As a result, most of the models performed satisfactorily, with a coefficient of determination $\left(R^{2}\right)$ greater than 0.95 . In case of ebullition, the $\mathrm{CH}_{4}$ concentration inside the chamber would deviate from the normal trend. Most of the $\mathrm{CH}_{4}$ concentrations measured immediately after the ebullition point slightly decreased mainly because of the $\mathrm{CH}_{4}$ diffusion back to water when the $\mathrm{CH}_{4}$ concentration inside the chamber space increased suddenly through bubbling. To include the ebullition-induced $\mathrm{CH}_{4}$ emissions, we only used two measured concentrations: the first measurement (ambient concentration) and an ebullitionadjusted concentration that was obtained by adding the diffusion-induced concentration increment when ebullition occurred (Fig. 2). Specifically, when ebullition occurred during the first $20 \mathrm{~min}$, we obtained the ebullition-adjusted concentration by summing up concentration on $20 \mathrm{~min}$ and the 2 -fold incremental concentration derived from concentration between the third and fourth sampling times. When the ebullition occurred at the third sampling, we summed up the concentration at $40 \mathrm{~min}$ and the incremental concentration between the first and second sampling times. When the ebullition occurred at the fourth sampling, we used the first and fourth sampling concentrations directly to calculate the slope of the total efflux.

Samplings took place at a monthly interval from January 2011 to December 2014 at three sites in Poyang $\mathrm{Hu}$ (Fig. 1): site A (Luoxingdun: $29^{\circ} 3^{\prime} 29^{\prime \prime} \mathrm{N}, 116^{\circ} 16^{\prime} 49^{\prime \prime} \mathrm{E}$ ), site B (Mantianxing: $29^{\circ} 34^{\prime} 25^{\prime \prime} \mathrm{N}, 116^{\circ} 13^{\prime} 29^{\prime \prime} \mathrm{E}$ ), and site $\mathrm{C}$ (Huoyanshan: $29^{\circ} 39^{\prime} 0^{\prime \prime} \mathrm{N}, 116^{\circ} 16^{\prime} 11^{\prime \prime} \mathrm{E}$ ). The mean water depth at our sampling sites was $3 \mathrm{~m}$. The sampling sites lacked aquatic plants. Our previous study examined the spatial pattern of the $\mathrm{CH}_{4}$ efflux from the lake (Liu et al., 2013). Therefore, we focused on the multi-seasonal dynamics of $\mathrm{CH}_{4}$ efflux from the current study. At each site, four chambers were placed approximately $10 \mathrm{~m}$ away from a small boat to minimize disturbance. Measurements were conducted from the early morning to the late afternoon with about six cycles of measurements for each chamber, except for days when the diel-cycle measurements were taken. We conducted four $24 \mathrm{~h}$ measurements at the three sites to examine the diel variations of $\mathrm{CH}_{4}$ effluxes: 24-25 July 2011, 5-6 September 2012, 13-14 January 2013, and 14-15 January 2015. These measurements were conducted every $2 \mathrm{~h}$ from 08:00 to $08: 00 \mathrm{CST}(\mathrm{GMT}+8)$ the next day, providing 12 cycles of measurements for each chamber per $24 \mathrm{~h}$. 

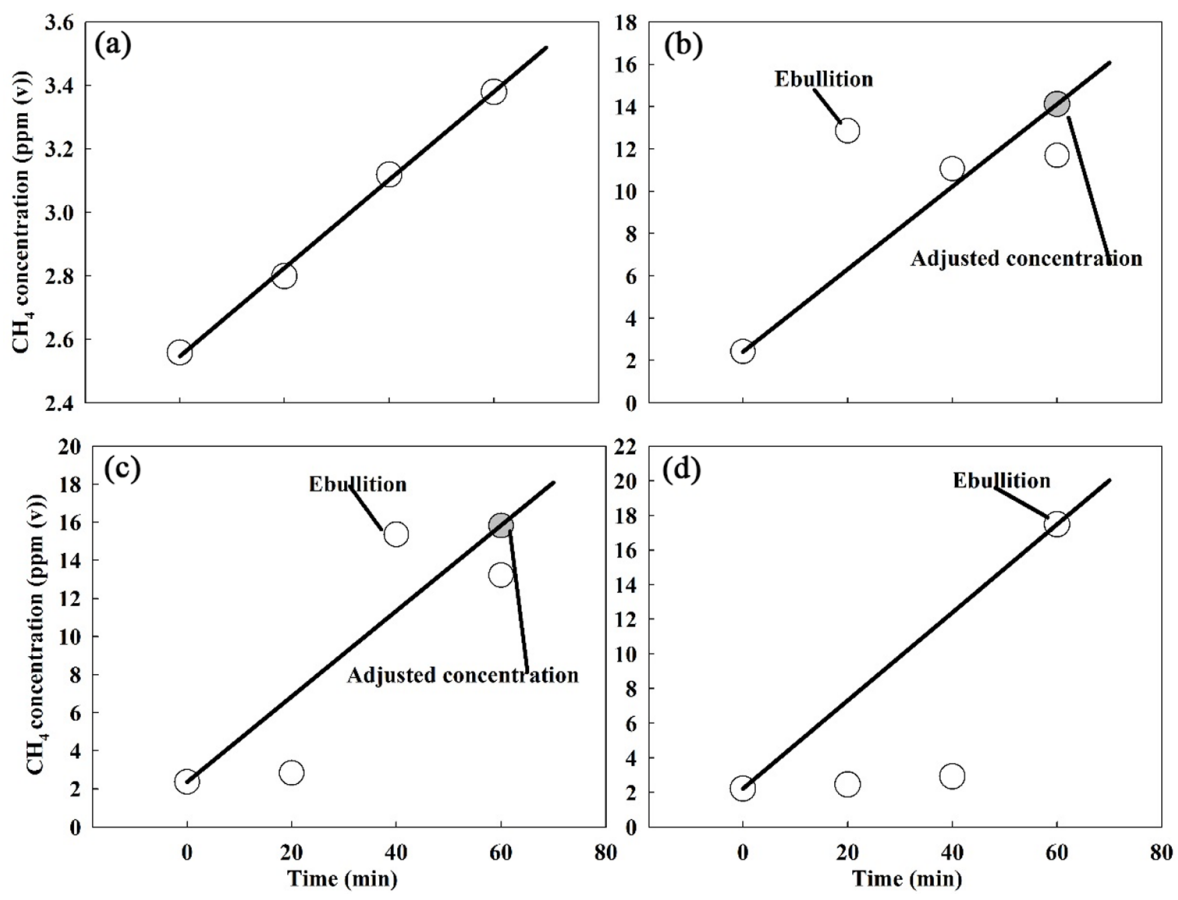

Figure 2. Examples of calculating the slope of total effluxes, including diffusive and ebullitive effluxes. All the concentrations are presented in original (volumetric parts per million units). White circles represent the $\mathrm{CH}_{4}$ concentrations at different sampling times. Grey circles represent the adjusted concentration. Black trend lines represent the data used for the total efflux calculation. The different letters in the figure panels mean different occurrence times for ebullition: no ebullition (a), occurrence of ebullition at $20 \mathrm{~min}$ (b), $40 \mathrm{~min}$ (c), and $60 \mathrm{~min}$ (d).

\subsection{Environmental variables}

Various environmental variables were also measured in the lake sediment, surface water, and atmosphere at each individual site and then averaged them when we used them. We collected surface water and sediment samples $(0-15 \mathrm{~cm})$ using a plexiglass water grab and a stainless-steel sediment sampler ( $3 \mathrm{~cm}$ in diameter) after obtaining gas samples. The water and sediment samples were immediately stored in plastic bottles and bags, respectively. Then, all the samples were stored in ice coolers and transported to a laboratory for analysis within 1 week. In addition, we measured the wind speed at about $1.5 \mathrm{~m}$ above the water surface using a portable anemometer (Testo 410-1, Testo, Germany) and the surface sediment (0$15 \mathrm{~cm})$ temperature using a mercury thermometer. We used a multi-parametric probe (556 MPS, YSI, USA) to measure the water quality factors in situ, such as electrical conductivity and dissolved oxygen (DO) content, at each sampling site from June 2013 to June 2014. The water levels in the lake were obtained from the Xingzi Hydrological Station, about $20 \mathrm{~km}$ from our sampling sites.

In the laboratory, the $\mathrm{pH}$ values of the water and sediment samples were measured using a $\mathrm{pH}$ meter (Delta 320, Mettler-Toledo, Switzerland). Chemical oxygen demand (COD) was measured using the spectrophotometric detection method based on the Griess reaction (Jirka and Carter, 1975; Yao et al., 2015). Chl $a$ concentration was measured via spectrophotometry (Rasilo et al., 2015; Yao et al., 2015), which was extracted in $90 \%$ ethanol and then analyzed spectrophotometrically at 750 and $665 \mathrm{~nm}$ in accordance with ISO 10260 (1992). The SS level in the lake water was measured by a gravimetric procedure, where the solids from the water sample were filtered, dried, and weighed to determine the total nonfilterable residue of the sample (Fishman and Friedman, 1989). TP concentration was measured using the molybdenum blue method after persulfate digestion (Karl and Tien, 1992; Yao et al., 2015). In addition, the nitrate $\left(\mathrm{NO}_{3}^{-}\right)$, ammonium $\left(\mathrm{NH}_{4}^{+}\right), \mathrm{TN}$, and dissolved organic carbon (DOC) contents in the water were measured using a total carbon and nitrogen analyzer using filtered water (Shimadzu TOC-VCSH + TN module, Shimadzu, Japan). The sediment $\mathrm{TN}$ and organic carbon contents after total sediment acidification with $\mathrm{HCl} 1 \mathrm{~N}$ were determined using a vario MAX CN element analyzer (NA Series 2, CE Instruments, Germany). The values of measured environmental variables in our study were given in Table S1 in the Supplement.

Considering the different sampling periods, we divided the environmental variables into three groups (Table S1). The first group included sediment temperature, sediment total nitrogen content, water level, DOC content in the water, $\mathrm{pH}$ in the sediment, $\mathrm{NH}_{4}^{+}$and $\mathrm{NO}_{3}^{-}$concentrations in the water and sediment, sediment organic carbon content, the ratio of carbon and nitrogen, and the mean daily wind speed over a 48-month period. The second group included TN, TP, COD, 
and Chl $a$ contents in the water, which were sampled between June 2011 and December 2014. We sampled the third group variables from June 2013 to June 2014, including DO content, conductivity, and $\mathrm{pH}$ in the water.

\subsection{Data analysis}

We averaged the $\mathrm{CH}_{4}$ effluxes of the three sites to minimize the effect of the spatial variation of $\mathrm{CH}_{4}$ efflux on the temporal dynamics of the efflux. One-way ANOVA followed by a post-hoc Tukey's test and paired $t$ test were used to analyze the seasonal differences in the $\mathrm{CH}_{4}$ effluxes. We employed stepwise multiple regressions to identify the environmental factors driving the $\mathrm{CH}_{4}$ effluxes on different temporal scales. We also used regression and correlation analyses to determine the relationships between independent variables and $\mathrm{CH}_{4}$ effluxes. In addition, we considered each study site as a random effect in linear mixed effects models in order to take into account $\mathrm{CH}_{4}$ efflux variations among three sites when we investigated seasonal and diurnal variations as well as the relationships between $\mathrm{CH}_{4}$ efflux and environmental variables. We used the van't Hoff equation to calculate the temperature sensitivity $\left(Q_{10}=e^{10 b}\right.$, where $b$ is the exponent of the exponential function between $\mathrm{CH}_{4}$ efflux and sediment temperature) of $\mathrm{CH}_{4}$ efflux (Xu and Qi, 2001; Wei et al., 2015). All statistical analyses were performed using the SPSS 17.0 statistical software (SPSS Inc., Chicago, IL, USA), and graphs were created using the Sigma Plot 11.0 program (Systat Software Inc., San Jose, CA, USA).

\section{Results}

\section{1 $\mathrm{CH}_{4}$ effluxes in Poyang $\mathrm{Hu}$}

\subsubsection{Seasonal $\mathrm{CH}_{4}$ effluxes}

The seasonal variations of $\mathrm{CH}_{4}$ effluxes in Poyang Hu were prominent, demonstrating a similar pattern to that of seasonal temperature (Fig. 3). In general, the annual maximum $\mathrm{CH}_{4}$ effluxes occurred in summer and the minimum in winter. The $\mathrm{CH}_{4}$ efflux increased slowly in early spring and then rapidly in May, reaching its maximum in July. After reaching the maximum, the $\mathrm{CH}_{4}$ efflux decreased sharply in August and September and then slowly before reaching its minimum in January (Fig. 3). Significant differences in the mean $\mathrm{CH}_{4}$ effluxes existed between summer and the other three seasons throughout the 4 years $(p<0.05)$, whereas the differences in the $\mathrm{CH}_{4}$ effluxes among the spring, autumn, and winter seasons were not statistically significant $(p>0.05)$ (Table 1$)$. Additionally, the site effect was not statistically significant over the 4-year period (Table S2). The differences among the three sites were minor, with a 4-year mean of $0.53,0.55$, and $0.54 \mathrm{mmol} \mathrm{m}^{-2} \mathrm{day}^{-1}$. In particular, the seasonal patterns of $\mathrm{CH}_{4}$ effluxes at the three sites were similar and also in line with the seasonal pattern averaged over the three sites.

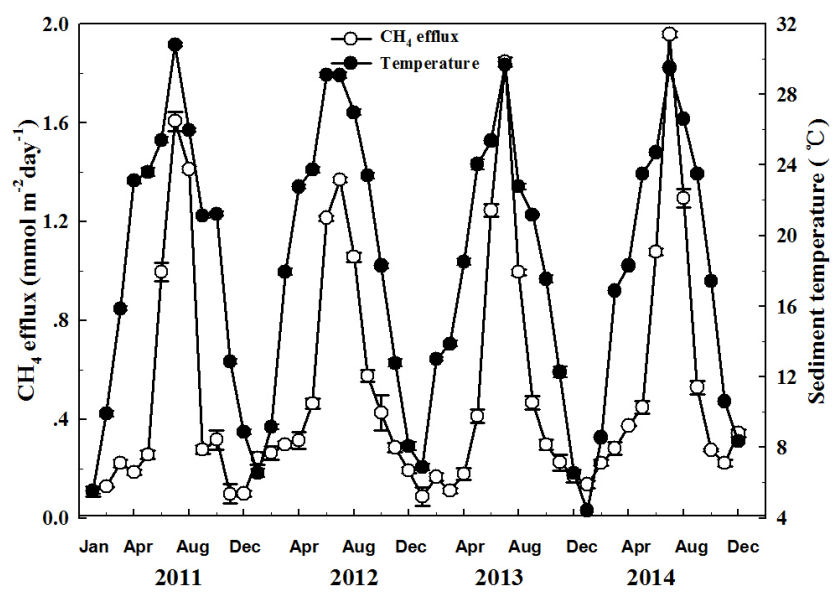

Figure 3. Seasonal variations of $\mathrm{CH}_{4}$ effluxes and sediment temperatures in Poyang $\mathrm{Hu}$. White circles represent the variation of $\mathrm{CH}_{4}$ effluxes, and black circles describe the variation of sediment temperature in the 4-year period.

Table 1. Seasonal mean of $\mathrm{CH}_{4}$ effluxes with the chamber measurements in Poyang Hu.

\begin{tabular}{lr}
\hline Season & $\mathrm{CH}_{4}$ efflux $\left(\mathrm{mmol} \mathrm{m}^{-2} \mathrm{day}^{-1}\right)$ \\
\hline Spring (Mar-May) & $0.30 \pm 0.11 \mathrm{bd}$ \\
Summer (Jun-Aug) & $1.34 \pm 0.32 \mathrm{a}$ \\
Autumn (Sep-Nov) & $0.33 \pm 0.14 \mathrm{~b}$ \\
Winter (Dec-Feb) & $0.18 \pm 0.077 \mathrm{~cd}$ \\
\hline
\end{tabular}

Note: means with different letters are significantly different as determined by multiple comparisons on a seasonal scale (one-way ANOVA, post hoc Tukey test, $p<0.05$ ).

\subsubsection{Diel $\mathrm{CH}_{4}$ effluxes}

The $\mathrm{CH}_{4}$ effluxes in Poyang $\mathrm{Hu}$ also exhibited apparent variations within 1 day because the daily maximum appeared late in the morning (10:00-12:00) and the minimum early in the morning the next day (04:00-06:00). The diel pattern of the $\mathrm{CH}_{4}$ efflux was asymmetric, fast increasing in the morning from 08:00 to 12:00 and slowly decreasing in the afternoon and during the night, especially in the summer (Fig. 4). However, the diel pattern of the $\mathrm{CH}_{4}$ efflux was inconsistent. For example, the diel pattern on 13-14 January 2013 was an exception, when the maximum efflux occurred around 06:00 on 14 January and a severe cold front with heavy fogs enveloped the Poyang Hu area in the early morning of 14 January. The $\mathrm{CH}_{4}$ efflux magnitudes were significantly larger during summer compared to winter. The $\mathrm{CH}_{4}$ efflux could also change abruptly throughout 1 day. For example, the efflux dropped sharply from 0.068 to $-0.012 \mathrm{mmol} \mathrm{m}^{-2} \mathrm{~h}^{-1}$ within barely $2 \mathrm{~h}$, as observed on 23 July 2011, indicating that the lake switched from a $\mathrm{CH}_{4}$ source to a sink within a short period of time (Fig. 4a). This abrupt change was also observed in the afternoon of 28 August 2012 (Fig. 4b). Furthermore, we 
Table 2. Correlation relationship between seasonal $\mathrm{CH}_{4}$ efflux and environmental factors.

\begin{tabular}{lrlr}
\hline Environmental factors & Correlation coefficient & Environmental factors & Correlation coefficient \\
\hline Dissolved oxygen & $-0.74^{\mathrm{b}}$ & Sediment-NO & -0.2 \\
Sediment nitrogen & $0.37^{\mathrm{a}}$ & Sediment-pH & -0.13 \\
Sediment carbon & 0.24 & Water-COD & -0.016 \\
pH in the water & -0.29 & Water-NO & -0.24 \\
Sediment C/N & -0.064 & Water-NH & $-0.36^{\mathrm{a}}$ \\
Conductivity & -0.37 & Water-chl $a$ & $0.46^{\mathrm{a}}$ \\
Wind speed & 0.008 & Water-TN & $-0.35^{\mathrm{a}}$ \\
DOC & -0.015 & Water-TP & 0.11 \\
\hline
\end{tabular}

Note: asterisks indicate statistically significant differences between $\mathrm{CH}_{4}$ efflux and environmental factors $\left({ }^{\mathrm{a}} p<0.05 ;{ }^{\mathrm{b}} p<0.01\right)$.
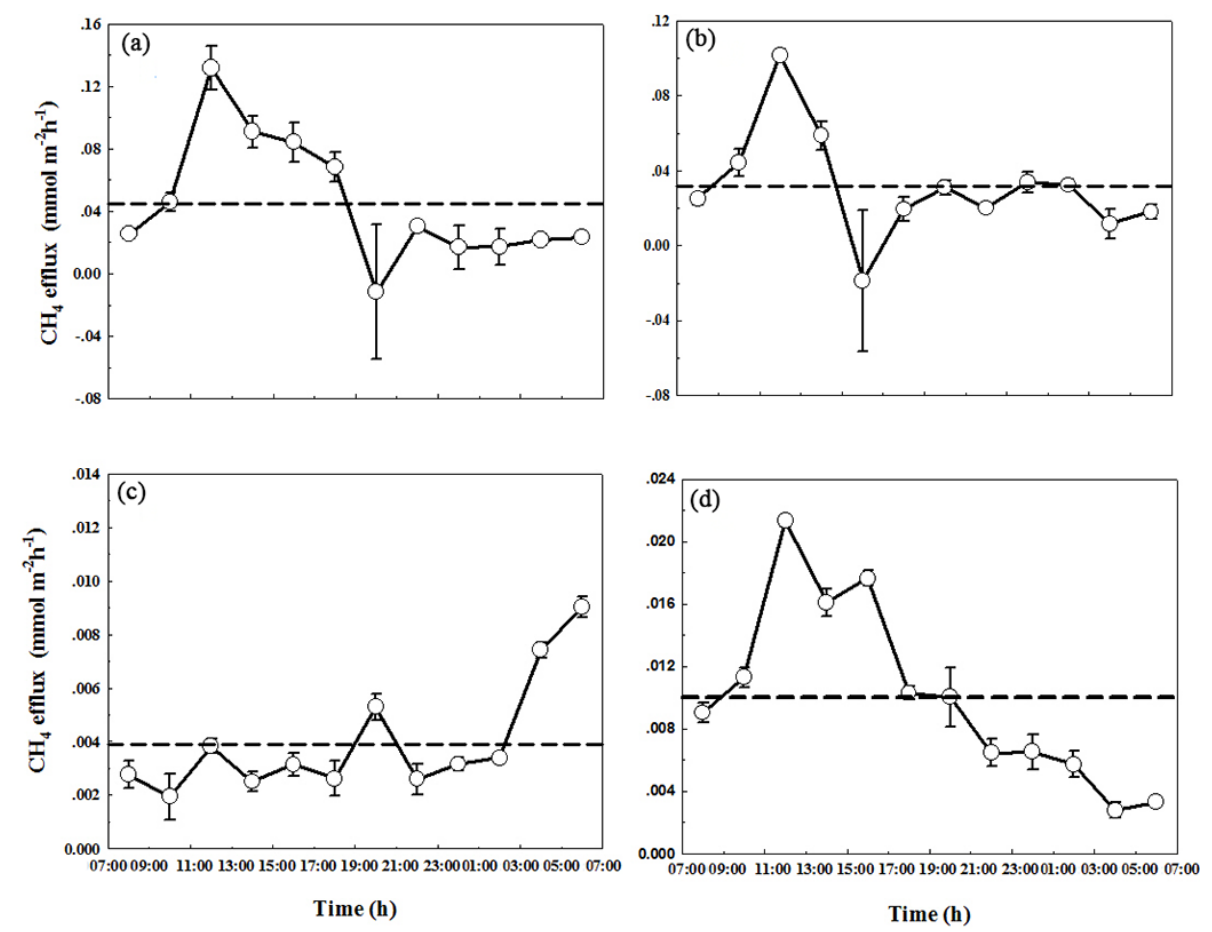

Figure 4. Diel variations of $\mathrm{CH}_{4}$ effluxes in Poyang Hu. Different panels present the diel variations of the $\mathrm{CH}_{4}$ effluxes in $24-$ 25 July 2011 (a), 5-6 September 2012 (b), 13-14 January 2013 (c), and 14-15 January 2015 (d). White circles describe the diel variations of the $\mathrm{CH}_{4}$ effluxes. Horizontal short dashed lines mean the average value of the diel $\mathrm{CH}_{4}$ effluxes.

compared the differences of diurnal patterns at each site for the four diel samplings. Our results showed that the diel patterns of $\mathrm{CH}_{4}$ effluxes were similar at the three sites for each diel investigation (Fig. 5), and the site effect was not statistically significant (Table S3). The diel pattern of the $\mathrm{CH}_{4}$ efflux was somewhat different during certain hours such as from 22:00 to 00:00 on 24 July 2011.

\subsection{Relationships between $\mathrm{CH}_{4}$ efflux and environmental variables}

\subsubsection{Simple regression relationships between $\mathrm{CH}_{4}$ efflux and environmental variables}

In our study, $\mathrm{CH}_{4}$ effluxes increased exponentially with sediment temperature for both the summer and other seasons (Fig. 6). The $\mathrm{CH}_{4}$ effluxes were more sensitive to temperature in the summer than in other seasons. The temperature sensitivity, indicated by the $Q_{10}$ values, was 2.04 and 1.67 in the summer and the other three seasons, respectively (Fig. 6). 
Table 3. Multivariate regressions between seasonal $\mathrm{CH}_{4}$ efflux and environment factors

\begin{tabular}{lrlrrr}
\hline No. & Number of variables & Regression equation & $n$ & $R^{2}$ & $p$ \\
\hline Group 1 & 12 & EffluxCH $_{4}=-10.48+0.57 \mathrm{ST}+65.06 \mathrm{SNC}$ & 48 & 0.65 & 0.004 \\
Group 1 + Group 2 & 16 & EffluxCH $_{4}=-12.66+0.57 \mathrm{ST}+90.81 \mathrm{SNC}$ & 43 & 0.73 & 0 \\
Group 1 + Group 2 & 19 & EffluxCH $_{4}=-3.89+0.56 \mathrm{ST}+102.88 \mathrm{SNC}$ & 19 & 0.89 & 0 \\
+ Group 3 & & & & \\
\hline
\end{tabular}

Note: variables in Group 1 included sediment temperature (ST), sediment total nitrogen content (SNC), water level, DOC content in the water, $\mathrm{pH}$ in the sediment, $\mathrm{NH}_{4}^{+}$and $\mathrm{NO}_{3}^{-}$concentrations in the water and in the sediment, sediment organic carbon content, the ratio of carbon and nitrogen, and the mean daily wind speed. Variables in Group 2 included TN, TP, COD, and Chl $a$ contents in the water. Variables in Group 3 included DO content, conductivity, and $\mathrm{pH}$ in the water
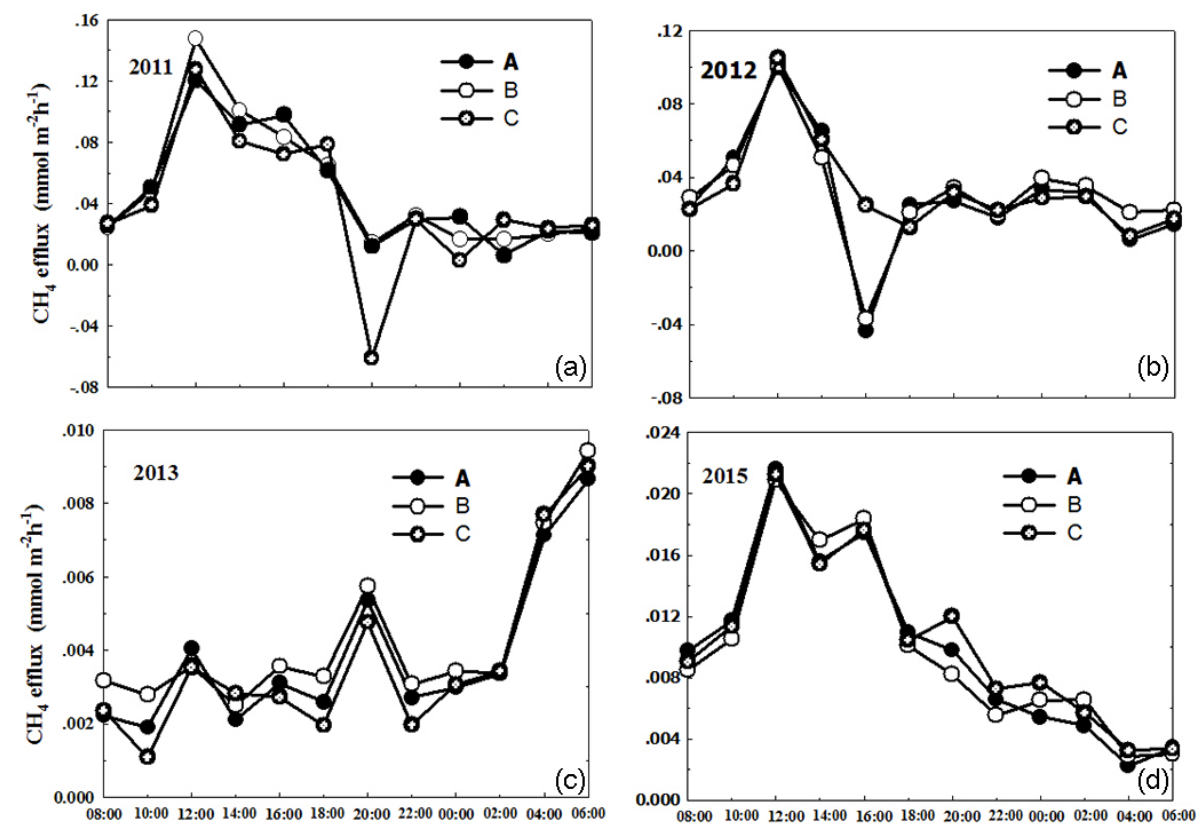

Figure 5. Diel variations of $\mathrm{CH}_{4}$ effluxes among three sites. Different panels present the diel variations of the $\mathrm{CH}_{4}$ effluxes on $24-$ 25 July 2011 (a), 5-6 September 2012 (b), 13-14 January 2013 (c), and 14-15 January 2015 (d).

We found that $\mathrm{CH}_{4}$ effluxes were also greatly associated with other climate and environmental variables in both lake water and sediments. We found that $\mathrm{CH}_{4}$ effluxes were negatively correlated with $\mathrm{NH}_{4}^{+}$, $\mathrm{TN}$, and $\mathrm{DO}$ concentrations in the lake water but positively with $\mathrm{Chl} a$ content in the water and TN content in the sediment (Table 2). Furthermore, we found that other environmental factors, such as DOC content in the water, $\mathrm{pH}$ in the water and in the sediment, $\mathrm{NO}_{3}^{-}$concentrations in the water and in the sediment, COD, and TP in the water, had insignificant $(p>0.05)$ relationships with $\mathrm{CH}_{4}$ effluxes in Poyang $\mathrm{Hu}$.

In the current study, we also found that the relationship between $\mathrm{CH}_{4}$ effluxes and wind speed was scale-dependent. On the diel scale, wind speed was significantly correlated $(p<0.03)$ with $\mathrm{CH}_{4}$ effluxes for the average of the three sites on the diel scale (Fig. 7) but was weakly correlated with $\mathrm{CH}_{4}$ effluxes on the diurnal and seasonal scales (Fig. 7). In addition, the relationships between wind speed and $\mathrm{CH}_{4}$ ef- fluxes for each individual site were similar to the relationships for the average of the three sites though the regression coefficients for each individual site were slightly different but not in a statistically significant way $(p>0.25)$.

\subsubsection{Multiple-regression relationships between $\mathrm{CH}_{4}$ efflux and environmental variables}

In the current study, environmental factors differed in importance depending on the timescale in the stepwise multipleregression analyses. The results of stepwise multiple regressions on a seasonal scale showed that the sediment temperature, sediment TN content, DO, and TP content in the water were significant predictors of $\mathrm{CH}_{4}$ effluxes (Table 3). It should be noted that multicollinearity did not occur among these significant variables (Table S4). Specifically, sediment temperature and sediment TN content explained $65 \%$ of the variation in $\mathrm{CH}_{4}$ effluxes for 4 years when we used the first group of factors. The sediment temperature and $\mathrm{TN}$ content 
Table 4. Mean $\mathrm{CH}_{4}$ effluxes in Poyang $\mathrm{Hu}$ in comparison with other large lakes.

\begin{tabular}{|c|c|c|c|c|c|c|}
\hline Lake & Lake size $\left(\mathrm{km}^{2}\right)$ & Region & Climate & $\begin{array}{r}\mathrm{CH}_{4} \text { efflux } \\
\left(\mathrm{mmol} \mathrm{m}^{-2} \mathrm{day}^{-1}\right)\end{array}$ & References & $\begin{array}{l}\text { Sampling } \\
\text { period }\end{array}$ \\
\hline 11 lakes & 1 & Laurentians, Canada & Boreal & 4.08 & Rasilo et al. (2015) & $11 / 0^{\mathrm{d}}$ \\
\hline Fiolen & 1.5 & Sweden & Boreal & 0.02 & Bastviken et al. (2004) & Once \\
\hline 31 lakes & 2 & Eastmain, Canada & Boreal & 0.58 & Rasilo et al. (2015) & $14 / 17^{* \mathrm{~d}}$ \\
\hline Kevätön & 4 & Finland & Boreal & 0.22 & Huttunen et al. (2003) & 12 times \\
\hline 45 lakes & 5 & Côte-Nord, Canada & Boreal & 1.17 & Rasilo et al. (2015) & $45 / 0^{\mathrm{d}}$ \\
\hline 20 lakes & 7 & James Bay, Canada & Boreal & 1.08 & Rasilo et al. (2015) & $14 / 6^{\mathrm{d}}$ \\
\hline Dillon Lake & 13 & North America & Boreal & 0.61 & Smith and Lewis (1992) & 9 times \\
\hline Lake Mendota & 39.4 & North America & Boreal & 0.5 & Fallon et al. (1980) & 6 times \\
\hline 27 lakes & 41 & Abitibi, Canada & Boreal & 1.67 & Rasilo et al. (2015) & $21 / 6^{\mathrm{d}}$ \\
\hline 26 lakes & 47 & Chicoutimi, Canada & Boreal & 1.08 & Rasilo et al. (2015) & $19 / 7^{d}$ \\
\hline 16 lakes & 171 & Chibougamau, Canada & Boreal & 0.17 & Rasilo et al. (2015) & $14 / 2^{\mathrm{d}}$ \\
\hline 48 lakes & 242 & Schefferville, Canada & Boreal & 0.42 & Rasilo et al. (2015) & $48 / 0^{\mathrm{d}}$ \\
\hline Võrtsjärv & 270 & Estonia & Boreal & $1.28^{\mathrm{b}} / 2.09^{\mathrm{c}}$ & Rõõm et al. (2014) & 21 times \\
\hline 6 lake & $>100,2024015.8^{\mathrm{a}}$ & Worldwide & Mainly boreal & 0.06 & Holgerson and Raymond (2016) & Multiple times \\
\hline 18 lakes & range $10-100,597789.3^{a}$ & Worldwide & Mainly boreal & 0.1 & Holgerson and Raymond (2016) & Multiple times \\
\hline 43 lakes & range $1-10,782073.8^{\mathrm{a}}$ & Worldwide & Mainly boreal & 0.12 & Holgerson and Raymond (2016) & Multiple times \\
\hline Nojiri-ko & 4.4 & Japan & Temperate & 0.06 & Utsumi et al. (1998b) & 6 times \\
\hline 5 lakes & range $1-11,3436^{\mathrm{a}}$ & Netherlands & Temperate & 5.85 & Schrier-Uijl et al. (2011) & twice \\
\hline Kasumigaura & 168 & Japan & Temperate & 0.26 & Utsumi et al. (1998a) & 72 times \\
\hline Biwa-ko & 674 & Japan & Temperate & 0.27 & Miyajima et al. (1997) & 3 times \\
\hline Biandantang & 3.3 & China & Subtropical & 1.32 & Xing et al. (2006) & 12 times \\
\hline Donghu & 27.9 & China & Subtropical & 1.46 & Xing et al. (2005) & 48 times \\
\hline Poyang $\mathrm{Hu}$ & 3283 & China & Subtropical & 0.54 & Present study & 48 times \\
\hline Baía do Biguá lake & 36.3 & Pantanal, South America & Tropical & $0.50^{\mathrm{b}} / 5.63^{\mathrm{c}}$ & Bastviken et al. (2010) & Once \\
\hline Tereza lake & 71.4 & Pantanal, South America & Tropical & $0.65^{\mathrm{b}} / 5.74^{\mathrm{c}}$ & Bastviken et al. (2010) & Once \\
\hline
\end{tabular}

Note: ${ }^{a}$ means total area of the given lake; ${ }^{b}$ means diffusive effluxes; ${ }^{c}$ means total effluxes, including diffusion and ebullition; ${ }^{\mathrm{d}}$ means number of lakes measured once/twice; ${ }^{*}$ means 24 lakes measured once/0 lakes measured twice in 2006, 8 lakes measured once/11 lakes measured twice in 2007, 0 lakes measured once/13 lakes measured twice in 2008, 2 lakes measured once/10 lakes measured twice in 2009.

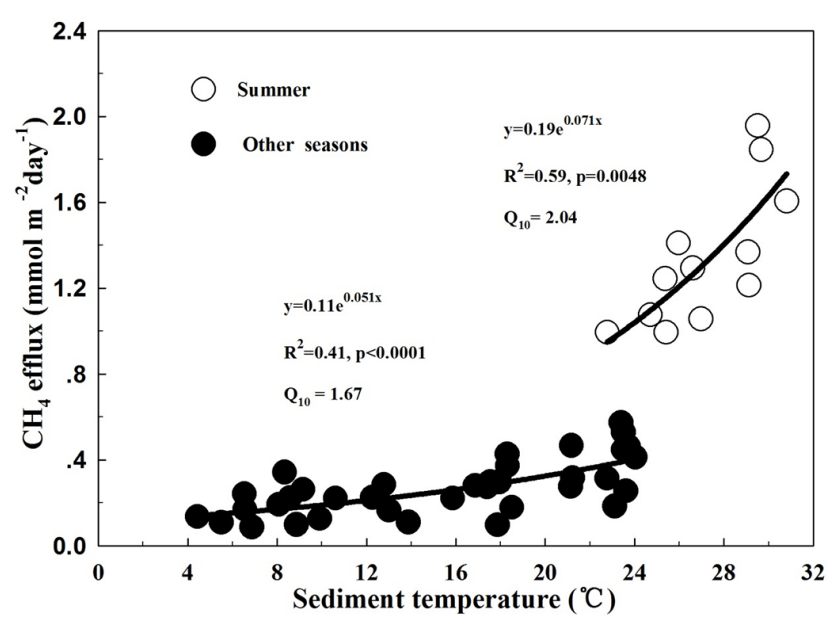

Figure 6. Relationship between sediment temperature and $\mathrm{CH}_{4}$ effluxes in Poyang $\mathrm{Hu}$. White circles represent the observed values of the diurnal mean $\mathrm{CH}_{4}$ effluxes and sediment temperature in summer, and black circles represent the observed values of the diurnal mean $\mathrm{CH}_{4}$ effluxes and sediment temperature in the other seasons in the 4-year period. Black lines represent the fitting curves of the relationship between $\mathrm{CH}_{4}$ effluxes and sediment temperature.

explained $73 \%$ of the $\mathrm{CH}_{4}$ efflux variations when the second group of variables was added to the first group. The sediment temperature, sediment TN content, DO, and TP contents in the water explained $89 \%$ of the $\mathrm{CH}_{4}$ efflux variation when the three groups of variables were used together. Wind speed was the only significant variable for the $\mathrm{CH}_{4}$ efflux variations on a diel scale. Wind speed explained 58, 56, 84, and $86 \%$ of the $\mathrm{CH}_{4}$ efflux variations in 24-25 July 2011, 5-6 September 2012, 13-14 January 2013, and 14-15 January 2015, respectively (Fig. 7a-d). In addition, the same environmental variables were selected in the final model for each individual site as for the average of the three sites though the regression coefficients were slightly different (Table S5) but not in a statistically significant way $(p>0.20)$.

\section{Discussion}

\section{1 $\mathrm{CH}_{4}$ effluxes in Poyang $\mathrm{Hu}$}

The mean $\mathrm{CH}_{4}$ emission in Poyang $\mathrm{Hu}$ was moderately higher than that in other large lakes of more than $1 \mathrm{~km}^{2}$ in the world. The mean $\mathrm{CH}_{4}$ emission $\left(0.54 \mathrm{mmol} \mathrm{m}^{-2}\right.$ day $\left.{ }^{-1}\right)$ was within the reported range of approximately $0.022-$ $5.85 \mathrm{mmol} \mathrm{m}^{-2} \mathrm{day}^{-1}$ in boreal and temperate lakes over $1 \mathrm{~km}^{2}$ but was lower than diffusive effluxes in subtropical lakes and total effluxes (including diffusion and ebullition) in tropical lakes (Table 4). In addition, the mean $\mathrm{CH}_{4}$ emission in Poyang $\mathrm{Hu}$ was comparable to the diffusive effluxes in tropical lakes (Table 4). However, the mean $\mathrm{CH}_{4}$ efflux from Poyang $\mathrm{Hu}$ was only higher than those in other lakes over $100 \mathrm{~km}^{2}$ (except the Vorrtsjärv Lake). The lower $\mathrm{CH}_{4}$ emissions in our study may be attributed to the low concentration of carbon substrates in the water and sediments 

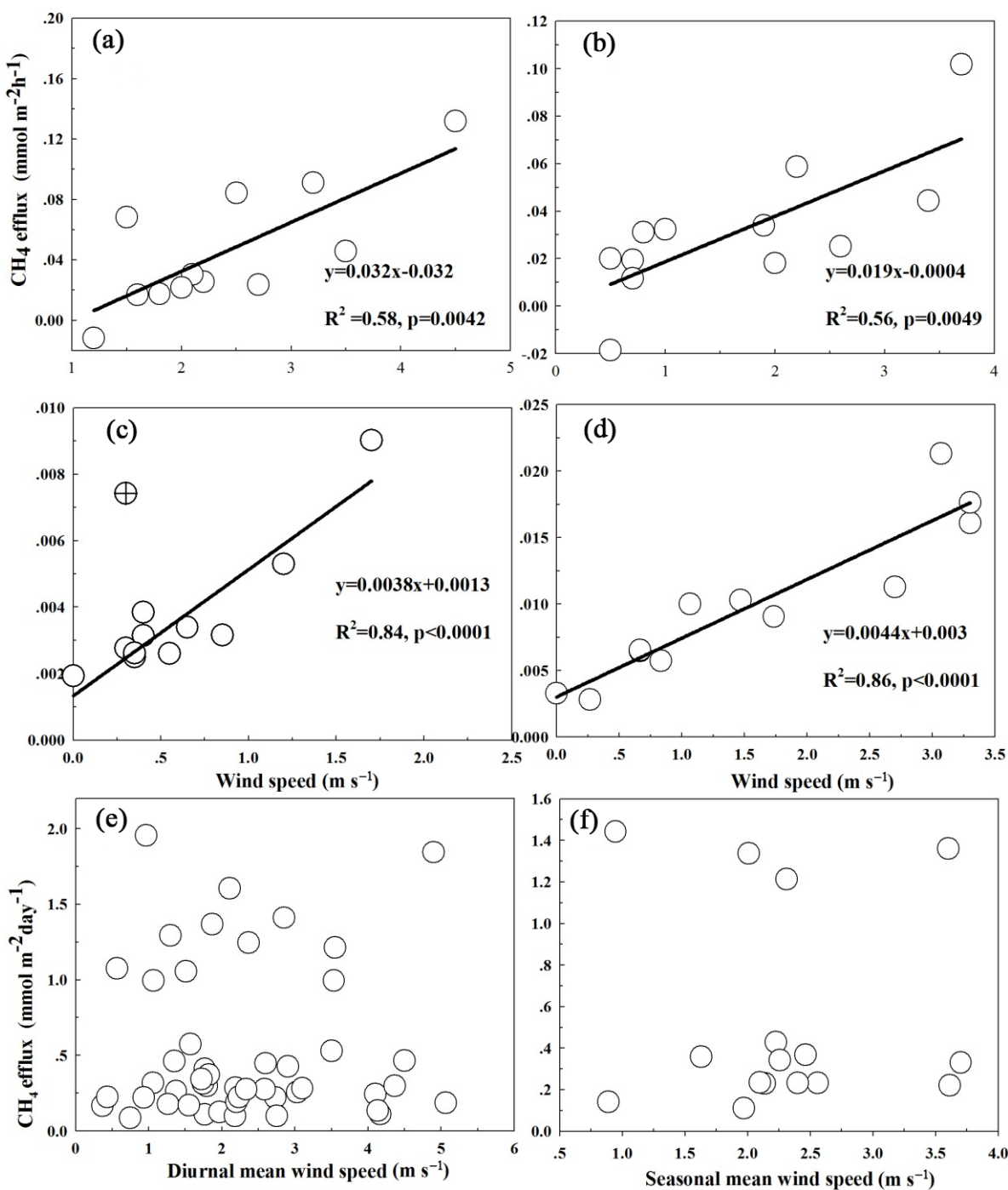

Figure 7. Relationships between $\mathrm{CH}_{4}$ effluxes and wind speed in Poyang $\mathrm{Hu}$. White circles represent the observed values of $\mathrm{CH}_{4}$ effluxes and wind speed. Different panels mean the variations of $\mathrm{CH}_{4}$ effluxes at a bihourly interval within 1 day, including in 24-25 July 2011 (a), 5-6 September 2012 (b), 13-14 January 2013 (c), and 14-15 January 2015 (d), on a diurnal scale (e), and on a seasonal scale (f). Panels (e, f) include all the measurements during the observation period. We excluded the white circle with black cross in (c) in the regression analysis because of a severe cold front.

in Poyang Hu. The DOC concentration in Poyang Hu was merely $3.3 \mathrm{mg} \mathrm{L}^{-1}$, which was much lower than that of the $5.8 \mathrm{mg} \mathrm{L}^{-1}$ in Biandantang Lake and $7.4 \mathrm{mg} \mathrm{L}^{-1}$ in Donghu Lake, which are two subtropical lakes in China (Xing et al., 2005, 2006). Poyang $\mathrm{Hu}$ also has a lower organic carbon content in its sediments than most other lakes. The average organic carbon content in the sediments in Poyang $\mathrm{Hu}$ was $0.89 \%$, which was much lower than that of $30.76 \%$ averaged over five temperate lakes (Schrier-Uijl et al., 2011) and slightly higher than that of nearly $0.75 \%$ in tropical lakes in the Pantanal region (Bastviken et al., 2010).

\section{2 $\mathrm{CH}_{4}$ effluxes in summer}

The $\mathrm{CH}_{4}$ effluxes in Poyang $\mathrm{Hu}$ were substantially greater in summer than in the other seasons, accounting for more than $63 \%$ of the annual total emissions. This finding suggests that summer is the critical season in managing the $\mathrm{CH}_{4}$ emissions from Poyang Hu. The high effluxes in summer may be attributed to the higher temperature, higher substrate availability, and greater temperature sensitivity during this season than the other seasons.

The high summer $\mathrm{CH}_{4}$ effluxes may due to high temperature in summer. The $\mathrm{CH}_{4}$ effluxes were highly correlated with the sediment temperature through an exponential function in our study. During the study period, the mean (June- 
August) air temperature in summer was $28.5^{\circ} \mathrm{C}$, whereas that in winter was only $5.9^{\circ} \mathrm{C}$. Our results confirmed the findings of previous studies that lake $\mathrm{CH}_{4}$ effluxes are driven by temperature (Bastviken et al., 2008; Marinho et al., 2009; PalmaSilva et al., 2013; Rõõm et al., 2014). This is supported by the fact that a warm temperature provides a high optimal temperature for methanogen growth (Nozhevnikova et al., 2007; Rooney-Varga et al., 2007; Duc et al., 2010) and the proportion of hydrogenotrophic methanogenesis (Borrel et al., 2011; Marotta et al., 2014). The high summer $\mathrm{CH}_{4}$ effluxes might also be because of the ample substrate supply in this season because the decomposition rate of new organic matter was much faster than that of old organic matter (Davidson and Janssens, 2006; Gudasz et al., 2010). In the present study, $\mathrm{CH}_{4}$ efflux positively correlated with the Chl $a$ content (Table 2) that was not correlated with other environmental factors (Table S4) and acted as an indicator of primary production. Earlier studies discovered a high amount of labile organic matter, including allochthonous inputs of terrestrial organic matter, during the summer flooding and autochthonous production within-lake by phytoplankton and benthic algae in summer (Crump et al., 2003; Xing et al., 2005, 2006; Bade et al., 2007). Previous studies showed that fresh organic carbon from dead algae stimulates $\mathrm{CH}_{4}$ emissions in lakes (Huttunen et al., 2002; Xing et al., 2005) because the degradation of dead alga and algal exudates are the precursors for $\mathrm{CH}_{4}$ production (Ferrón et al., 2012; Xiao et al., 2015; Liang et al., 2016). However, we did not find any correlation between the $\mathrm{CH}_{4}$ efflux and DOC content in the water $(p>0.05)$. The algal bloom in summer probably masked the DOC effect on stimulating $\mathrm{CH}_{4}$ production. Earlier studies demonstrated that $70-80 \%$ of DOC molecules in lakes are recalcitrant carbon (Tranvik and Kokalj, 1998; Wetzel, 2001).

The high summer $\mathrm{CH}_{4}$ effluxes were also driven by the greater temperature sensitivity during summer. The apparent $Q_{10}$ value in Poyang $\mathrm{Hu}$ was 2.04 in summer, which was much greater than the value of 1.67 in the other seasons (Fig. 6). This finding is inconsistent with previous studies in terrestrial and freshwater ecosystems (Davidson and Janssens, 2006; Gudasz et al., 2010; Yvon-Durocher et al., 2014), where the $Q_{10}$ values decreased apparently with the increase in temperature (Xu and Qi, 2001; Chen et al., 2010; Corkrey et al., 2012; Schipper et al., 2014). However, our result was supported by a recent finding that the temperature sensitivities $\left(Q_{10}\right)$ of $\mathrm{CH}_{4}$ effluxes from lake sediments are greater in the tropics than in boreal regions (Marotta et al., 2014). We speculate that the temperature effect on $Q_{10}$ was confounded by other factors, such as water level and substrate availability. The addition of a large amount of fresh carbon from summer floods could dramatically boost $\mathrm{CH}_{4}$ production and thus the apparent $Q_{10}$ values during summer.

\subsection{Timescale dependence of wind, substrate availability, and temperature effects on $\mathrm{CH}_{4}$ effluxes}

In this study, the effects of wind, substrate availability, and sediment temperature on $\mathrm{CH}_{4}$ effluxes were highly timescale dependent. The $\mathrm{CH}_{4}$ effluxes measured at bihourly intervals positively correlated with wind speed in both simple and multiple regressions (Fig. 7a-d, Table 2) but showed no correlation $(p>0.05)$ when the diurnal or seasonal average $\mathrm{CH}_{4}$ efflux and wind speed were applied (Fig. 7e-f). The effect of wind on $\mathrm{CH}_{4}$ effluxes was mainly through its effects on the transport, air pressure, and storage of $\mathrm{CH}_{4}$ from the bottom to the surface water (Abril et al., 2005; Hahm et al., 2006; Guérin et al., 2007). Gas diffusion in water is sensitive to pressure changes at the water-air interface ( $\mathrm{Pa}-$ ganelli et al., 1975; Massmann and Farrier, 1992; Striegl et al., 2001; Nachshon et al., 2012). High wind speed mechanically induces turbulences through friction in the water and brings $\mathrm{CH}_{4}$-rich water from the bottom to the surface in lakes (Wanninkhof, 1992; Palma-Silva et al., 2013; Xiao et al., 2013). The $\mathrm{CH}_{4}$ efflux rapidly decreases or even becomes negative (indicating $\mathrm{CH}_{4}$ absorption) to compensate for the deficits in the water profile caused by earlier winds when the wind declines or comes to a halt. Our results also confirmed that the $\mathrm{CH}_{4}$ efflux sharply declined to a negative value after strong wind events (Fig. 4). This wind effect only worked on short timescales, such as a bihourly one, when temperature only slightly changed and other biological processes, such as microbial community variation, were relatively stable. On a longer temporal scale, such as a seasonal scale as observed in the current study, the wind effect disappeared because the wind-stimulated $\mathrm{CH}_{4}$ effluxes and the post-wind (or between-gust) negative effluxes (absorptions) were compensated for. Our results suggest that wind exerts minor effects on $\mathrm{CH}_{4}$ effluxes on large temporal scales when temperature, water level, and substrate availability dominate. Our results also suggest that caution must be taken when one applies the empirical wind-speed-driven models developed based on short-term measurements to estimate $\mathrm{CH}_{4}$ effluxes over long periods, such as months or years.

Meanwhile, the $\mathrm{CH}_{4}$ effluxes measured at monthly intervals positively correlated with sediment temperature (Fig. 6), but the correlation disappeared when applied at bihourly intervals $(p>0.05)$. The lack of correlation between the $\mathrm{CH}_{4}$ efflux and sediment temperature as measured on a bihourly scale within 1 day can be explained by the small variation of sediment temperature within 1 day, ranging from 0.95 to $1.85^{\circ} \mathrm{C}$. Other factors, such as wind and atmospheric pressure, might shadow the weak temperature effect within 1 day. Instead, we found a high correlation between the bihourly measured $\mathrm{CH}_{4}$ effluxes and sediment temperature during the diel measurement period from 14 to 15 January 2015 $(r=0.88, p<0.0001)$. Further analyses showed that this temperature effect might be apparent and mainly caused by 
wind speed because the bihourly measured $\mathrm{CH}_{4}$ effluxes and wind speed were highly correlated only from 14 to 15 January 2015 and not on the other days $(r=0.90, p<0.0001)$. However, sediment temperature became the dominant factor on a seasonal scale when the temperature ranged from about $4.4^{\circ} \mathrm{C}$ in winter to $30.8^{\circ} \mathrm{C}$ in summer (Fig. 3). The sediment temperature and $\mathrm{CH}_{4}$ effluxes averaged over the diurnal period significantly correlated in the 4-year study period (Fig. 6). Our results suggest that the short-term $\mathrm{CH}_{4}$ efflux from Poyang $\mathrm{Hu}$ was regulated by wind speed, but the multi-seasonal $\mathrm{CH}_{4}$ efflux was ultimately controlled by sediment temperature and other biological (e.g., microbial activity) and biochemical (e.g., sediment carbon and nitrogen content) processes. Therefore, understanding and modeling the dynamics of $\mathrm{CH}_{4}$ effluxes on lake surfaces require the multi-seasonal measurements of effluxes and related biotic and abiotic factors in lake water and sediments. Finally, substrate availability, such as sediment TN content, TP, and $\mathrm{Chl} a$ contents in the water, also influenced $\mathrm{CH}_{4}$ effluxes on a seasonal scale in the current study (Tables 2,3). However, the effects disappeared when applied at bihourly intervals because the substrate did not change significantly within 1 day.

In addition to the abovementioned factors, the DO concentration in the water influenced the $\mathrm{CH}_{4}$ effluxes in the multivariate regression analysis. Specifically, the $\mathrm{CH}_{4}$ efflux closely correlated with the DO concentration in the water (Table 2). This close correlation can be explained by the aerobic $\mathrm{CH}_{4}$ oxidation in the water. Our result was supported by the previous finding that a high DO concentration in the water results in low $\mathrm{CH}_{4}$ emission (Rõõm et al., 2014; McNicol and Silver, 2015; Yang et al., 2015).

\section{Conclusion}

The average $\mathrm{CH}_{4}$ efflux from Poyang $\mathrm{Hu}$ during the 4-year study period was $0.54 \pm 0.053 \mathrm{mmol} \mathrm{m}^{-2} \mathrm{day}^{-1}$, which was moderately higher than that of the other lakes in the world. The $\mathrm{CH}_{4}$ efflux from Poyang $\mathrm{Hu}$ also featured high multiseasonal variations with the maximum efflux in July and the minimum in January. About $63 \%$ of the annual emissions occurred in summer, from June to August. On a seasonal scale, multivariate regression analyses revealed that sediment temperature, sediment TN content, TP, and DO contents in the water mainly regulated the $\mathrm{CH}_{4}$ effluxes. Simple and multivariate regression analyses showed that wind speed influenced the diel $\mathrm{CH}_{4}$ efflux variations. The effects of sediment temperature, substrate availability, and wind speed on $\mathrm{CH}_{4}$ effluxes were temporal scale dependent. The $\mathrm{CH}_{4}$ effluxes increased with the sediment temperature, sediment TN content, Chl $a$, and TP contents in the water on a seasonal scale but were not correlated with sediment temperature on a bihourly scale. In contrast to the temperature and substrate, the $\mathrm{CH}_{4}$ efflux positively and significantly correlated with wind speed within 1 day on a bihourly scale but was not correlated with wind speed on larger temporal scales, such as daily and seasonal scales. The timescale dependence of environmental controls on $\mathrm{CH}_{4}$ effluxes has important implications in modeling $\mathrm{CH}_{4}$ emissions.

Data availability. Mean data including seasonal and diel methane fluxes can be found in the Supplement.

\section{The Supplement related to this article is available online at doi:10.5194/bg-14-2019-2017-supplement.}

Competing interests. The authors declare that they have no conflict of interest.

Acknowledgements. This research was supported by the National Basic Research Program of China (973 Program, 2012CB417103), Assessment and Valuation of Ecosystem Services in Qinghai Province, China (No. 2013-N-556). We gratefully acknowledge the Poyang Lake Laboratory Wetland Ecosystem Research, CAS, for permission to access the study site and assistance with field work.

Edited by: A. Ito

Reviewed by: three anonymous referees

\section{References}

Abril, G., Guérin, F., Richard, S., Delmas, R., Galy-Lacaux, C., Gosse, P., Tremblay, A., Varfalvy, L., Dos Santos, M. A., and Matvienko, B.: Carbon dioxide and methane emissions and the carbon budget of a 10-year old tropical reservoir (Petit Saut, French Guiana), Global Biogeochem. Cy., 19, GB4007, doi:10.1029/2005GB002457, 2005.

Anthony, K. W. and Macintyre, S.: Nocturnal escape route for marsh gas, Nature, 535, 363-365, 2016.

Bade, D. L., Carpenter, S. R., Cole, J. J., Pace, M. L., Kritzberg, E., Van de Bogert, M. C., Cory, R. M., and McKnight, D. M.: Sources and fates of dissolved organic carbon in lakes as determined by whole-lake carbon isotope additions, Biogeochemistry, 84, 115-129, 2007.

Bartosiewicz, M., Laurion, I., and MacIntyre, S.: Greenhouse gas emission and storage in a small shallow lake, Hydrobiologia, 757, 101-115, 2015.

Bastviken, D., Cole, J., Pace, M., and Tranvik, L.: Methane emissions from lakes: dependence of lake characteristics, two regional assessments, and a global estimate, Global Biogeochem. Cy., 18, 1-12, 2004.

Bastviken, D., Cole, J. J., Pace, M. L., and Van de Bogert, M. C.: Fates of methane from different lake habitats: connecting wholelake budgets and $\mathrm{CH}_{4}$ emissions, J. Geophys. Res., 113, G02024, doi:10.1029/2007JG000608, 2008.

Bastviken, D., Santoro, A. L., Marotta, H., Pinho, L., Calheiros, D., and Crill, P.: Methane emissions from Pantanal, South America, during the low water Season: Toward more comprehensive sampling, Environ. Sci. Technol., 44, 5450-5455, 2010. 
Bastviken, D., Natchimuthu, S., and Panneer Selvam, B.: Response: inland water greenhouse gas emissions: when to model and when to measure?, Glob. Change Biol., 21, 1379-1380, 2015.

Borrel, G., Jézéquel, D., Biderre-Petit, C., Morel-Desrosiers, N., Morel, J. P., and Peyret, P.: Production and consumption of methane in freshwater lake ecosystems, Res. Microbiol., 162, 832-847, 2011.

Bridgham, S. D., Cadillo-Quiroz, H., Keller, J. K., and Zhuang, Q. L.: Methane emissions from wetlands: biogeochemical, microbial, and modeling perspectives from local to global scales, Glob. Change Biol., 19, 1325-1346, 2013.

Chanton, J. P.: Gas transport from methane-saturated, tidal freshwater and wetland sediments, Limnol. Oceanogr., 34, 807-819, 1989.

Chen, Y. G., Bai, X. H., Li, X. H., Hu, Z. X., and Liu, W. L.: Primary study of the methane flux on the water-air interface of eight lakes in winter, China, J. Lake Sci., 19, 11-17, 2007.

Chen, B. Y., Liu, S. R., Ge, J. P., and Chu, J. X.: Annual and seasonal variations of $Q_{10}$ soil respiration in the sub-alpine forests of the Eastern Qinghai-Tibet Plateau, China, Soil Biol. Biochem., 42, 1735-1742, 2010.

Chen, H., Zhu, Q. A., Peng, C. H., Wu, N., Wang, Y. F., and Fang, $\mathrm{X}$. Q.: Methane emissions from rice paddies natural wetlands, lakes in China: synthesis new estimate, Glob. Change Biol., 19, 19-32, 2013.

Corkrey, R., Olley, J., Ratkowsky, D., McMeekin, T., and Ross, T.: Universality of thermodynamic constants governing biological growth rates, Plos One, 7, e32003, doi:10.1371/journal.pone.0032003, 2012.

Crump, B. C., Kling, G. W., Bahr, M., and Hobbie, J. E.: Bacterioplankton community shifts in an Arctic Lake correlate with seasonal changes in organic matter source, Appl. Environ. Microb., 69, 2253-2268, 2003.

Davidson, E. A. and Janssens, I. A.: Temperature sensitivity of soil carbon decomposition and feedbacks to climate change, Nature, 440, 165-173, 2006.

Downing, J. A.: Emerging global role of small lakes and ponds: little things mean a lot, Limnetica, 29, 9-24, 2010.

Duan, X. N., Wang, X. K., Mu, Y. J., and Ouyang, Z. Y.: Seasonal and diurnal variations in methane emissions from Wuliangsu Lake in arid regions of China, Atmos. Environ., 39, 4479-4487, 2005.

Duc, N. T., Crill, P., and Bastviken, D.: Implications of temperature and sediment characteristics on methane formation and oxidation in lake sediments, Biogeochemistry, 100, 185-196, 2010.

Fallon, R. D., Harris, S., Hanson, R. S., and Brock, T. D.: The role of methane in internal carbon cycling in Lake Mendota during summer stratification, Limnol. Oceanogr., 25, 357-360, 1980.

Ferrón, S., Ho, D. T., Johnson, Z. I., and Huntley, M. E.: Air-water fluxes of $\mathrm{N}_{2} \mathrm{O}$ and $\mathrm{CH}_{4}$ during microalgae (Staurosira sp.) cultivation in an open raceway pond, Environ. Sci. Technol., 46, 10842-10848, 2012.

Fishman, M. J. and Friedman, L. C. (Eds.): Methods for determination of inorganic substances in water and fluvial sediments, US Geological Survey Techniques of Water-Resources Investigations, US Gov. Print. Off., Washington, D.C., book 5, chap. A1, p. $545,1989$.
Gudasz, C., Bastviken, D., Steger, K., Premke, K., Sobek, S., and Tranvik, L. J.: Temperature-controlled organic carbon mineralization in lake sediments, Nature, 466, 478-481, 2010.

Guérin, F., Abril, G., Serca, D., Delon, C., Richard, S., Delmas, R., Tremblay, A., and Varfalvy, L.: Gas transfer velocities of $\mathrm{CO}_{2}$ and $\mathrm{CH}_{4}$ in a tropical reservoir and its river downstream, J. Marine Syst., 66, 161-172, 2007.

Hahm, D., Kim, G., Lee, Y. W., Nam, S. Y., Kim, K. R., and Kim, K.: Tidal influence on the sea-to-air transfer of $\mathrm{CH}_{4}$ in the coastal ocean, Tellus B, 58, 88-94, 2006.

Hershey, A. E., Northington, R. M., and Whalen, S. C.: Substrate limitation of sediment methane flux, methane oxidation and use of stable isotopes for assessing methanogenesis pathways in a small arctic lake, Biogeochemistry, 117, 325-336, 2014.

Holgerson, M. A. and Raymond, P. A.: Large contribution to inland water $\mathrm{CO}_{2}$ and $\mathrm{CH}_{4}$ emissions from very small ponds, Nat. Geosci., 9, 222-150, 2016.

Huttunen, J. T., Väisänen, T. S., Hellsten, S. K., Heikkinen, M., Nykänen, H., Jungner, H., Niskanen, A., Virtanen, M. O., Lindqvist, O. V., Nenonen, O. S., and Martikainen, P. J.: Fluxes of $\mathrm{CH}_{4}, \mathrm{CO}_{2}$, and $\mathrm{N}_{2} \mathrm{O}$ in hydroelectric reservoirs Lokka and Porttipahta in the northern boreal zone in Finland, Global Biogeochem. Cy., 16, 1-17, 2002.

Huttunen, J. T., Alm, J., Liikanen, A., Juutinen, S., Larmola, T., Hammar, T., Silvola, L., and Martikainen, P. J.: Fluxes of methane, carbon dioxide and nitrous oxide in boreal lakes and potential anthropogenic effects on the aquatic greenhouse gas emissions, Chemosphere, 52, 609-621, 2003.

IPCC: Climate change 2013: the physical science basis, in: Contribution of Working Group I to the Fifth Assessment Report of the Intergovernmental Panel on Climate Change, edited by: Stocker, T. F., Qin, D., Plattner, G.-K., Tignor, M., Allen, S. K., Boschung, J., Nauels, A., Xia, Y., Bex, V., and Midgley, P. M., Cambridge University Press, Cambridge, United Kingdom and New York, NY, USA, p. 507, 2013.

ISO 10260: Water quality-Measurement of biochemical parameters-Spectrometric determination of the chlorophylla concentration, International Organization for Standardization, Geneve, Switzerland, 1992.

Jirka, A. M. and Carter, M. J.: Micro semi-automated analysis of surface and waste waters for chemical oxygen demand, Anal. Chem., 47, 1397-1402, 1975.

Juutinen, S., Rantakari, M., Kortelainen, P., Huttunen, J. T., Larmola, T., Alm, J., Silvola, J., and Martikainen, P. J.: Methane dynamics in different boreal lake types, Biogeosciences, 6, 209223, doi:10.5194/bg-6-209-2009, 2009.

Käki, T., Ojala, A., and Kankaala, P.: Diel variation in methane emissions from stands of Phragmites australis (Cav.) Trin. ex Steud. and Typha latifolia L. in a boreal lake, Aquat. Bot., 71, 259-271, 2001.

Karl, D. M. and Tien, G.: MAGIC: A sensitive and precise method for measuring dissolved phosphorus in aquatic environments, Limnol. Oceanogr., 37, 105-116, 1992.

Keller, M. and Stallard, F.: Methane emission by bubbling from Gatun Lake, Panama, J. Geophys. Res., 99, 8307-8319, 1994.

Li, S. Y. and Bush, R. T.: Revision of methane and carbon dioxide emissions from inland waters in India, Glob. Change Biol., 21, 6-8, 2015. 
Liang, X., Zhang, X. Y., Sun, Q., He, C. Q., Chen, X. P., Liu, X. Y., and Chen, Z. L.: The role of filamentous algae Spirogyra spp. in methane production and emissions in streams, Aquat. Sci., 78, 227-239, 2016.

Liikanen, A., Huttunen, J. T., Murtoniemi, T., Tanskanen, H., Väisänen, T., Silvola, J., Alm, J., and Martikainen, P. J.: Spatial and seasonal variation in greenhouse gas and nutrient dynamics and their interactions in the sediments of a boreal eutrophic lake, Biogeochemistry, 65, 83-103, 2003.

Liu, L. X. and Xu, M.: Microbial biomass in sediments affects greenhouse gas effluxes in Poyang Lake in China, J. Freshwater Ecol., 31, 109-121, 2016.

Liu, L. X., Xu, M., Lin, M., and Zhang, X.: Spatial variability of greenhouse gas effluxes and their controlling factors in the Poyang Lake in China, Pol. J. Environ. Stud., 22, 749-758, 2013.

Liu, L. X., Xu, M., Qiu, S., and Shen, R. C.: Spatial patterns of benthic bacteria communities in a large lake, Int. Rev. Hydrobiol., 100, 97-105, 2015.

Lorke, A., Bodmer, P., Noss, C., Alshboul, Z., Koschorreck, M., Somlai-Haase, C., Bastviken, D., Flury, S., McGinnis, D. F., Maeck, A., Müller, D., and Premke, K.: Technical note: drifting versus anchored flux chambers for measuring greenhouse gas emissions from running waters, Biogeosciences, 12, 7013-7024, doi:10.5194/bg-12-7013-2015, 2015.

Marinho, C. C., Palma-Silva, C., Albertoni, E. F., Trindade, C. R., Esteves, F. A.: Seasonal dynamics of methane in the water column of two subtropical lakes differing in trophic status, Braz. J. Biol., 69, 631-637, 2009.

Marotta, H., Pinho, L., Gudasz, C., Bastviken, D., Tranvik, L. J., and Enrich-Prast, A.: Greenhouse gas production in low-latitude lake sediments responds strongly to warming, Nature Climate Change, 4, 467-470, 2014.

Massmann, J. and Farrier, D. F.: Effects of atmospheric pressures on gas transport in the vadose zone, Water Resour. Res., 28, 777791, 1992.

McGinnis, D. F., Kirillin, G., Tang, K. W., Flury, S., Bodmer, P., Engelhardt, C., Casper, P., and Grossart, H. P.: Enhancing surface methane fluxes from an oligotrophic lake: exploring the microbubble hypothesis, Environ. Sci. Technol., 49, 873-880, 2015.

McNicol, G. and Silver, W. L.: Non-linear response of carbon dioxide and methane emissions to oxygen availability in a drained Histosol, Biogeochemistry, 123, 299-306, 2015.

Miyajima, T., Yamada, Y., Wada, E., Nakajima, T., Koitabashi, T., Hanba, Y. T., and Yoshi, K.: Distribution of greenhouse gases, nitrite, and $\delta^{13} \mathrm{C}$ of dissolved inorganic carbon in Lake Biwa: Implications for hypolimnetic metabolism, Biogeochemistry, 36, 205-211, 1997

Nachshon, U., Dragila, M., and Weisbrod, N.: From atmospheric winds to fracture ventilation: Cause and effect, J. Geophys. Res., 117, G02016, doi:10.1029/2011JG001898, 2012.

Nozhevnikova, A. N., Nekrasova, V., Ammann, A., Zehnder, A. J. B., Wehrli, B., and Holliger, C.: Influence of temperature and high acetate concentrations on methanogenensis in lake sediment slurries, FEMS Microbiol. Ecol., 62, 336-344, 2007.

Ortiz-Llorente, M. J. and Alvarez-Cobelas, M.: Comparison of biogenic methane emissions from unmanaged estuaries, lakes, oceans, rivers and wetlands, Atmos. Environ., 59, 328-337, 2012
Paganelli, C. V., Rahn, A. A., and Wangensteen, O. D.: Diffusion in the gas phase: the effects of ambient pressure and gas composition, Respir. Physiol., 25, 247-258, 1975.

Palma-Silva, C., Marinho, C. C., Albertoni, E. F., Giacomini, L. B., Barros, M. P. F., Furlanetto, L. M., Trindade, C. R. T., and de Assis Esteves, F.: Methane emissions in two small shallow neotropical lakes: the role of temperature and trophic level, Atmos. Environ., 81, 373-379, 2013.

Podgrajsek, E., Sahlée, E., Bastviken, D., Holst, J., Lindroth, A., Tranvik, L., and Rutgersson, A.: Comparison of floating chamber and eddy covariance measurements of lake greenhouse gas fluxes, Biogeosciences, 11, 4225-4233, doi:10.5194/bg-114225-2014, 2014.

Poindexter, C. M., Baldocchi, D. D., Matthes, J. H., Knox, S. H., and Variano, E. A.: The contribution of an overlooked transport process to a wetland's methane emissions, Geophys. Res. Lett., 43, 6276-6284, 2016.

Rasilo, T., Prairie, Y. T., and del Giorgio, P. A.: Large-scale patterns in summer diffusive $\mathrm{CH}_{4}$ fluxes across boreal lakes, and contribution to diffusive $\mathrm{C}$ emissions, Glob. Change Biol., 21, 1124-1139, 2015.

Rõõm, E. I., Nõges, P., Feldmann, T., Tuvikene, L., Kisand, A., Teearu, H., and Nõges, T.: Years are not brothers: two-year comparison of greenhouse gas fluxes in large shallow Lake Võrtsjärv, Estonia, J. Hydrol., 519, 1594-1606, 2014.

Rooney-Varga, J. N., Giewat, M. W., Duddleston, K. N., Chanton, J. P., and Hines, M. E.: Links between archaeal community structure, vegetation type and methanogenic pathway in Alaskan peatlands, FEMS Microbiol. Ecol., 60, 240-251, 2007.

Schipper, L. A., Hobbs, J. K., Rutledge, S., and Arcus, V. L.: Thermodynamic theory explains the temperature optima of soil microbial processes and high $Q_{10}$ values at low temperatures, Glob. Change Biol., 20, 3578-3586, 2014.

Schrier-Uijl, A. P., Veraart, A. J., Leffelaar, P. A., Berendse, F., and Veenendaal, E. M.: Release of $\mathrm{CO}_{2}$ and $\mathrm{CH}_{4}$ from lakes and drainage ditches in temperate wetlands, Biogeochemistry, 102, 265-279, 2011.

Segers, R.: Methane production and methane consumption: a review of process underlying wetland methane fluxes, Biogeochemistry, 41, 23-51, 1998.

Serrano-Silva, N., Sarria-Guzmán, Y., Dendooven, L., and LunaGuido, M.: Methanogenesis and methanotrophy in soil: a review, Pedosphere, 24, 291-307, 2014.

Smith, L. K. and Lewis, W. M.: Seasonality of methane emissions from five lakes and associated wetlands of the Colorado Rockies, Global Biogeochem. Cy., 6, 323-338, 1992.

Striegl, R. G., Kortelainen, P., Chanton, J. P., Wickland, K. P., Bugna, G. C., and Rantakari, M.: Carbon dioxide partial pressure and ${ }^{13} \mathrm{C}$ content of north temperate and boreal lakes at spring ice melt, Limnol. Oceanogr., 46, 941-945, 2001.

Sun, X., Song, C., Guo, Y., Wang, X., Yang, G., Li, Y., Mao, R., and Lu, Y.: Effect of plants on methane emissions from a temperate marsh in different seasons, Atmos. Environ., 60, 277-282, 2012.

Townsend-Small, A., Disbennett, D., Fernandez, J. M., Ransohoff, R. W., Mackay, R., and Bourbonniere, R. A.: Quantifying emissions of methane derived from anaerobic organic matter respiration and natural gas extraction in Lake Erie, Limnol. Oceanogr., 61, S356-S366, 2016. 
Tranvik, L. and Kokalj, S.: Decreased biodegradability of algal DOC due to interactive effects of UV radiation and humic matter, Aquat. Microb. Ecol., 14, 301-307, 1998.

Utsumi, M., Nojiri, Y., Nakamura, T., Nozawa, T., Otsuki, A., and Seki, H.: Oxidation of dissolved methane in a eutrophic, shallow lake: Lake Kasumigaura, Japan, Limnol. Oceanogr., 43, 471480, 1998a.

Utsumi, M., Nojiri, Y., Nakamura, T., Nozawa, T., Otsuki, A., Takamura, N., Watanabe, M., and Seki, H.: Dynamics of dissolved methane and methane oxidation in dimictic Lake Nojiri during winter, Limnol. Oceanogr., 43, 10-17, 1998b.

Vachon, D. and Prairie, Y. T.: The ecosystem size and shape dependence of gas transfer velocity versus wind speed relationships in lakes, Can. J. Fish. Aquat. Sci., 70, 1757-1764, 2013.

van Bodegom, P. M. and Scholten, J. C. M.: Microbial processes of $\mathrm{CH}_{4}$ production in a rice paddy soil: Model and experimental validation, Geochim. Cosmochim. Ac., 65, 2055-2066, 2001.

Verpoorter, C., Kutser, T., Seekell, D. A., and Tranvik, L. J.: A global inventory of lakes based on high-resolution satellite imagery, Geophys. Res. Lett., 41, 6396-6402, 2014.

Wang, Y. Y., Yu, X. B., Li, W. H., Xu, J., Chen, Y. W., and Fan, N.: Potential influence of water level changes on energy flows in a lake food web, Chinese Sci. Bull., 56, 2794-2802, 2011.

Wanninkhof, R.: Relationship between wind speed and gas exchange over the ocean, J. Geophys. Res., 97, 7373-7382, 1992.

Wei, D., Xu, R., Tarchen, T., Wang, Y. S., and Wang, Y. H.: Considerable methane uptake by alpine grasslands despite the cold climate: in situ measurements on the central Tibetan Plateau, 20082013, Glob. Change Biol., 21, 777-788, 2015.

Wik, M., Thornton, B. F., Bastviken, D., Maclntyre, S., Varner, R. K., and Crill, P. M.: Energy input is primary controller of methane bubbling in subarctic lakes, Geophys. Res. Lett., 41, 555-560, 2014.

Wetzel, R. G.: Limnology: Lake and River ecosystems, Academic Press, Harcourt Science and Technology Company, 2457024577, 2001.

Xiao, S. B., Wang, Y. C., Liu, D. F., Yang, Z. J., Lei, D., and Zhang, C.: Diel and seasonal variation of methane and carbon dioxide fluxes at Site Guojiaba, the Three Gorges Reservoir, J. Environ. Sci., 25, 2065-2071, 2013.

Xiao, S. B., Liu, W. G., Yang, H., Liu, D., Wang, Y., and Peng, F.: Extreme methane bubbling emissions from a subtropical shallow eutrophic pond, Austin Biometrics and Biostatistics, 1, 1-6, 2015.

Xing, Y. P., Xie, P., Yang, H., Ni, L. Y., Wang, Y. S., and Tang, W. H.: Diel variation of methane fluxes in summer in a eutrophic subtropical Lake in China, J. Freshwater Ecol., 19, 639-644, 2004.
Xing, Y. P., Xie, P., Yang, H., Ni, L. Y., Wang, Y. S., and Rong, K. W.: Methane and carbon dioxide fluxes from a shallow hypereutrophic subtropical lake in China, Atmos. Environ., 39, 55325540, 2005.

Xing, Y. P., Xie, P., Yang, H., Wu, A. P., and Ni, L. Y.: The change of gaseous carbon fluxes following the switch of dominant producers from macrophytes to algae in a shallow subtropical lake of China, Atmos. Environ., 40, 8034-8043, 2006.

$\mathrm{Xu}, \mathrm{M}$. and Qi, Y.: Spatial and seasonal variations of $Q_{10}$ determined by soil respiration measurements at a Sierra Nevadan forest, Global Biogeochem. Cy., 15, 687-696, 2001.

Yang, H., Xie, P., Ni, L. Y., and Flower, R. J.: Underestimation of $\mathrm{CH}_{4}$ Emission from Freshwater Lakes in China. Environ, Sci. Technol., 45, 4203-4204, 2011.

Yang, S. S., Chen, I. C., Liu, C. P., Liu, L. Y., and Chang, C. H.: Carbon dioxide and methane emissions from Tanswei River in Northern Taiwan, Atmos. Pollut. Res., 6, 52-61, 2015.

Yao, X., Wang, S. R., Ni, Z. K., and Jiao, L. X.: The response of water quality variation in Poyang Lake (Jiangxi, People's Republic of China) to hydrological changes using historical data and DOM fluorescence, Environ. Sci. Pollut. R., 22, 3032-3042, 2015.

Ye, X. C., Zhang, Q., Bai, L., and Hu, Q.: A modeling study of catchment discharge to Poyang Lake under future climate in China, Quaternary Int., 244, 221-229, 2011.

Yvon-Durocher, G., Allen, A. P., Bastviken, D., Conrad, R., Gudasz, C., St-Pierre, A., Thanh-Duc, N., and del Giorgio, P. A.: Methane fluxes show consistent temperature dependence across microbial to ecosystem scales, Nature, 507, 488-491, 2014.

Zhao, Y., Sherman, B., Ford, P., Demarty, M., DelSontro, T., Harby, A., Tremblay, A., Øverjordet, I. B., Zhao, X. F., Hansen, B. H., and $\mathrm{Wu}, \mathrm{B} .: \mathrm{A}$ comparison of methods for the measurement of $\mathrm{CO}_{2}$ and $\mathrm{CH}_{4}$ emissions from surface water reservoirs: Results from an international workshop held at Three Gorges Dam, June 2012, Limnol. Oceanogr., 13, 15-29, 2015.

Zhu, H. H. and Zhang, B.: Poyang Lake-hydrology, biology, sediment, wetland, exploitation andrenovation, in: University of science and technology of China Press, Hefei, 97-99, 1997.

Zhu, D., Wu, Y., Chen, H., He, Y. X., and Wu, N.: Intense methane ebullition from open water area of a shallow peatland lake on the eastern Tibetan Plateau, Sci. Total Environ., 542, 57-64, 2016. 